\title{
Ocular argyrosis in a jeweller
}

\author{
Yogish Kamath, Akanksha Sinha
}

Department of Ophthalmology, Kasturba Medical College, Manipal University, Manipal, Karnataka, India

\section{Correspondence to} Dr Yogish Kamath, dryogishkamath@yahoo.co.in

\section{DESCRIPTION}

A 50-year-old jeweller presented with a 6-month history of diminution of vision for near sight with his old glasses. His best corrected visual acuity was 6/6, N6 in both eyes. On slit-lamp biomicroscopic examination in both eyes, he had a grey-black pigmentation of the periorbital skin and lid margins (figure 1). The lower and medial bulbar conjunctivae also exhibited a similar discolouration, more prominent at the medial canthal region (figure 2). The corneal descemet membrane had a slate grey pigmentation more prominent towards the limbal region (figures 3 and 4). The rest of the anterior and posterior segment findings were unremarkable. Intraocular pressure by applanation tonometry was within normal limits. He refused any biochemical analysis of blood or urine.

Although a differential diagnosis of melanoma of the conjunctiva was initially considered, the characteristic descemet layer deposits, and his

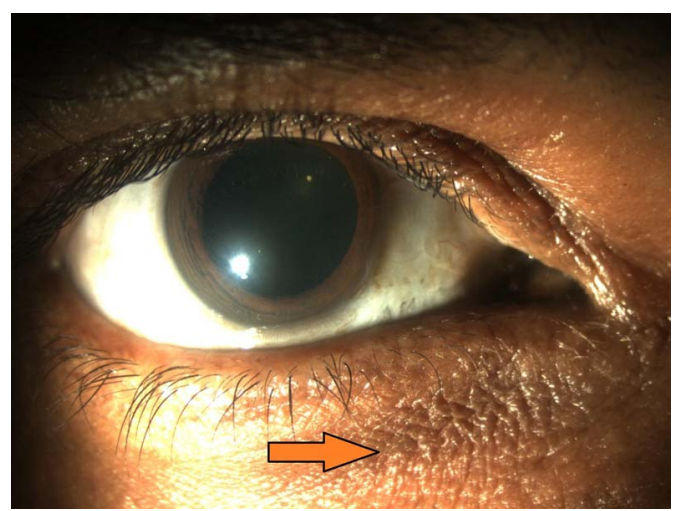

Figure 1 Greyish black pigmentation of eyelid skin.

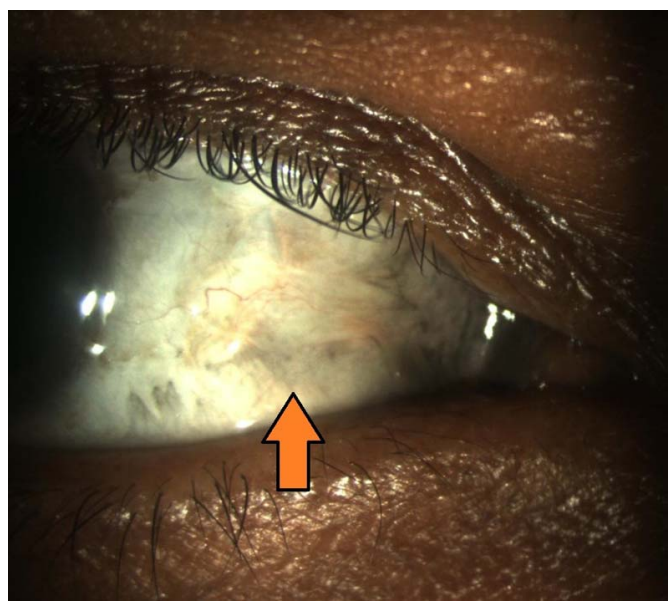

Figure 2 Greyish black pigmentation of the conjunctiva near medial canthus.

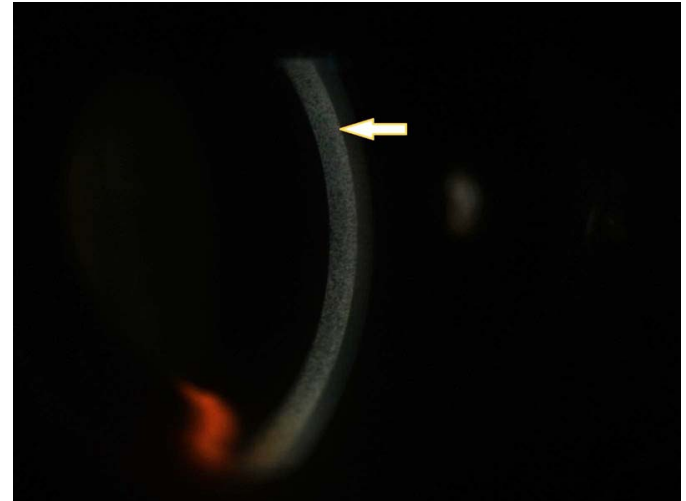

Figure 3 Slit-lamp biomicrosopy of the cornea showing grey deposits in deeper layers.

occupational history of predominantly crafting silver ornaments led to the clinical diagnosis of ocular argyrosis. The incidence of ocular argyrosis has considerably decreased after the cessation of use of colloidal silver as an ocular disinfectant, ${ }^{1}$ and better safety measures in mirror and battery manufacturing industries. ${ }^{2}$ There have been isolated reports following silver clip disintegration after previous strabismus surgery, prolonged eye rubbing after contact with photographic developing solution $^{1}$ and use of eye cosmetics. ${ }^{3}$ Pala et al. ${ }^{4}$ have described a case similar to ours where there was a prolonged history of crafting silver articles. The use of gloves and face shield was probably a deterrent to the skill and fine dexterity involved in the crafting of silver jewellery by our patient, who had been in the profession for over 35 years. However, in view of the suspected association between ocular argyrosis and sight threatening open angle glaucoma, ${ }^{5}$ the use of protective gear especially in such situations of prolonged exposure is advisable.

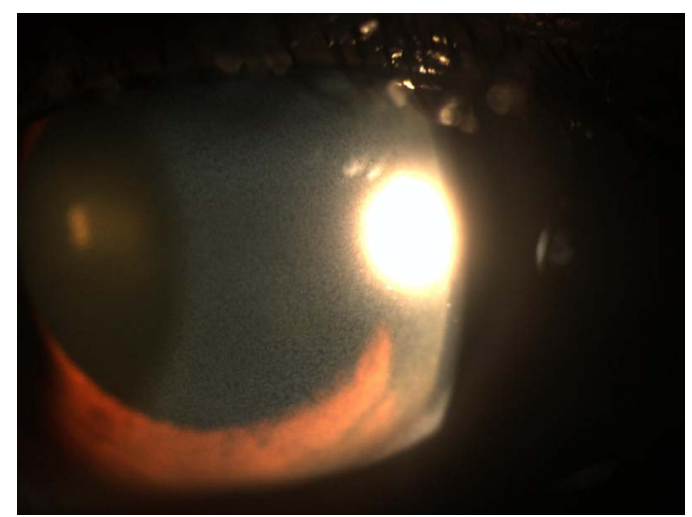

Figure 4 Diffuse distribution of the grey deposits in deeper corneal layers. 


\section{Learning points}

- Ocular argyrosis is the deposition of silver in the eye, predominantly involving the conjunctiva and cornea

- Occupational exposure is seen in jewellers handling silver articles for prolonged duration

- Prevention is possible with the use of protective gloves and face shields

Contributors YK was involved in the conception and design, acquisition and interpretation of data; and drafting of the article. AS was involved in the acquisition and analysis of the data as well as revising the draft of the article. Both were involved in the final approval before submission.
Competing interests None.

Patient consent Obtained.

Provenance and peer review Not commissioned; externally peer reviewed.

\section{REFERENCES}

1 Zografos L, Uffer S, Chamot L. Unilateral conjunctival-corneal argyrosis simulating conjunctival melanoma. Arch Ophthalmol 2003;121:1483-7.

2 Drake PL, Hazelwood KJ. Exposure-related health effects of silver and silver compounds: a review. Ann Occup Hyg 2005;49:575-85.

3 Gallardo MJ, Randleman JB, Price KM, et al. Ocular argyrosis after long term self application of eyelash tint. Am J Ophthalmol 2006;141:198-200.

4 Pala G, Fronterre A, Scafa F, et al. Ocular argyrosis in a silver craftsman. J Occup Health 2008;50:521-4.

5 Friedman DS, Terebuh A. Argyrosis in a patient with glaucoma. Ophthalmic Surg 1995;26:274.

Copyright 2013 BMJ Publishing Group. All rights reserved. For permission to reuse any of this content visit

http://group.bmj.com/group/rights-licensing/permissions.

BMJ Case Report Fellows may re-use this article for personal use and teaching without any further permission.

Become a Fellow of BMJ Case Reports today and you can:

- Submit as many cases as you like

- Enjoy fast sympathetic peer review and rapid publication of accepted articles

- Access all the published articles

- Re-use any of the published material for personal use and teaching without further permission

For information on Institutional Fellowships contact consortiasales@bmjgroup.com

Visit casereports.bmj.com for more articles like this and to become a Fellow 